\title{
PRÓBA OCENY EFEKTÓW ABSORPCJI ŚRODKÓW Z FUNDUSZY EUROPEJSKICH NA ROZWÓJ WYKORZYSTANIA ODNAWIALNYCH ŹRÓDEŁ ENERGII W WOJEWÓDZTWIE LUBELSKIM
}

\author{
Piotr Gradziuk*, Barbara Gradziuk ${ }^{* *}$ \\ *Katedra Ekonomii i Zarządzania Państwowej \\ Szkoły Wyższej im. Papieża Jana Pawła II w Białej Podlaskiej \\ Kierownik Katedry: prof. dr hab. Mieczysław Adamowicz \\ ** Katedra Zarządzania i Marketingu Uniwersytetu Przyrodniczego w Lublinie \\ Kierownik Katedry: dr hab. Eugenia Czernyszewicz, prof. UP
}

\begin{abstract}
Słowa kluczowe: odnawialne źródła energii (OZE), programy wsparcia, Regionalny Program Operacyjny, Program Rozwoju Obszarów Wiejskich, województwo lubelskie

Key words: renewable energy, support programs, Regional Operational Programme, Rural Development Programme, Lubelskie Voivodship
\end{abstract}

\begin{abstract}
S y n o p s i s. W opracowaniu przedstawiono wyniki badań, których celem była ocena efektów absorpcji funduszy europejskich na inwestycje z zakresu odnawialnych źródeł energii w woj. lubelskim oraz sformułowanie wstępnych rekomendacji na przyszły okres programowania. W ramach RPO WL i PROW (3.2.1) w woj. lubelskim zamontowano ponad 34 tys. instalacji o mocy 189,2 MWt i 4,1 MWe, przeważnie kolektorów słonecznych $(95,8 \%)$, kotłów na biomasę $(2,3 \%)$ i paneli fotowoltaicznych $(1,9 \%)$. Efektem zrealizowanych projektów było zmniejszenie zużycia paliw konwencjonalnych na obszarach wiejskich o około $4 \% \mathrm{w}$ ciągu roku, co jest równoważne wartości energetycznej 19 tys. t węgla kamiennego. Działania podjęte w ramach analizowanych programów przyczyniły się również do redukcji emisji $\mathrm{CO}_{2}$ o około 1,7 tys. t, podstawowego gazu cieplarnianego oraz pyłów i innych zanieczyszczeń.
\end{abstract}

\section{WSTĘP}

Współczesną politykę energetyczną krajów rozwiniętych cechuje systematyczne zmniejszanie udziału tradycyjnych, kopalnych nośników energii. Ich miejsce coraz częściej zajmują źródła odnawialne (OZE). Wynika to głównie z czterech przesłanek. Pierwszą najkrócej można określić, cytując Alvina Toflera: Warunkiem istnienia każdej cywilizacji - starej czy nowej jest energia [Toffler 1997, s. 38]. W efekcie bardzo wysokiej i ciągle rosnącej konsumpcji energii wytwarzanej głównie z paliw kopalnych oraz rozwoju transportu, na przełomie lat 60 . i 70. XX w. zaczęły pojawiać się symptomy kryzysu energetycznego. Coraz częściej występowały też wzrosty cen surowców energetycznych, powodowane konfliktami politycznymi, zwłaszcza po 1974 r. (embargo OPEC, rewolucja irańska czy wojna w Zatoce Perskiej). Według raportu International Energy Outlook 2002 przygotowa- 
nego przez Międzynarodową Agencję Energii w latach 2000-2020 prognozowano dalszy znaczny wzrost konsumpcji energii, który miał wynieść 60\% i zwiększyć się z 382 do 612 kwadrylionów (1024) Btu [International... 2003]. Przewidywania te okazały się trafne, albowiem do 2016 r. zużycie energii na świecie zwiększyło się o 42\% w stosunku do 2000 r. W najbardziej prawdopodobnym scenariuszu (Current Policies), opracowywanym przez Międzynarodową Agencję Energetyki, globalne zapotrzebowanie na energię pierwotną do 2035 r. wzrośnie o około 30\% w stosunku do roku 2011 [Key 2014].

Przesłanka druga to troska o środowisko. Intensywne wykorzystanie i przetwarzanie tradycyjnych surowców energetycznych wywiera bardzo niekorzystny wpływ na zasoby natury. Główne zagrożenie dla środowiska stanowią zmiany klimatyczne powodowane antropogennym podgrzaniem atmosfery w wyniku wzrastającej koncentracji gazów szklarniowych, przede wszystkim $\mathrm{CO}_{2}$. Istnieje uzasadniona obawa, że w kolejnych dekadach zjawisko to może stanowić zagrożenie dla zdrowia i życia ludzi w większości regionów świata. Stąd też inicjatywy wielu środowisk i organizacji międzynarodowych zmierzające do podejmowania działań na rzecz ograniczania emisji gazów cieplarnianych. Jednym ze sposobów jest zwiększanie wykorzystania odnawialnych źródeł energii. Istotą polityki klimatycznej jest więc skierowanie aktywności gospodarczej na ścieżkę rozwoju mniej zależną (lub docelowo niezależną) od tradycyjnych źródeł energii, którymi są paliwa kopalne.

Kolejny ważny czynnik to stagnacja popytu na surowce rolnicze i produkty żywnościowe, która stała się barierą rozwoju rolnictwa. W krajach o rozwiniętej gospodarce pojawiły się nadwyżki surowców rolniczych, nastąpiło pogorszenie opłacalności i zmniejszenie dochodów z działalności rolniczej, wzrosła powierzchnia odłogów i gruntów czasowo wyłączonych z produkcji rolniczej. Dlatego też w wielu krajach duży nacisk położono na badania nad alternatywnymi sposobami zagospodarowania tych nadwyżek. Dominujące znaczenie uzyskał kierunek bioenergetyczny, głównie ze względu na wzrost zainteresowania pozyskiwaniem niewyczerpywalnych, czystych ekologicznie źródeł energii [Gradziuk, Wojtaszek 2001, Woś, Zegar 2002].

Przesłanka czwarta to bezpieczeństwo energetyczne. Odnawialne źródła energii przede wszystkim uniezależniają odbiorców od importu - co szczególnie ważne - z regionów niestabilnych politycznie. Ponadto z racji rozproszenia utrudniają ewentualną zmowę i próby manipulowania podażą w celu szantażowania odbiorców [Fiedor 2010]. Pozyskiwana tą drogą energia jest jednak w większości zastosowań droższa od konwencjonalnej, aczkolwiek czas pracuje na korzyść zasobów odnawialnych [Woś, Zegar 2002, s. 13]. Stąd też Unia Europejska i poszczególne jej państwa decydują się na wsparcie produkcji energii z odnawialnych źródeł, ponieważ jest to obecnie główny sposób realizacji narodowych celów wskaźnikowych, wynikających z pakietu energetyczno-klimatycznego, a w niedalekiej przyszłości także globalnej umowy klimatycznej uzgodnionej podczas odbywającej się w Paryżu w dniach 30.11-12.12.2015 roku XXI Konferencji Stron (Conference of the Parties - COP) Ramowej Konwencji Narodów Zjednoczonych w sprawie zmian klimatu (United Nations Framework Convention on Climate Change-UNFCCC). W Planie dziatania prowadzacym do przejścia na konkurencyjna gospodarkę niskoemisyjna do $2050 \mathrm{r}$. zapisano iż: Centralna rola energii w gospodarce niskoemisyjnej wiąże się ze znacznym wykorzystywaniem odnawialnych źródel energii, z których wiele charakteryzuje się zmienna wydajnością. Niezbędne sa zatem znaczne inwestycje w sieci, by przez cały czas zapewnić ciagłość dostaw energii [Komunikat... 2011, s. 8].

W opracowaniu przedstawiono wyniki badań, których celem była ocena efektów absorpcji funduszy europejskich na inwestycje z zakresu odnawialnych źródeł energii 
w woj. lubelskim oraz sformułowanie wstępnych rekomendacji na przyszły okres programowania. Źródło danych stanowiły informacje uzyskane w Departamentach Regionalnego Programu Operacyjnego Urzędu Marszałkowskiego Województwa Lubelskiego w Lublinie oraz Funduszy Europejskich Ministerstwa Energii.

\section{MECHANIZMY WSPIERANIA ROZWOJU ENERGETYKI ODNAWIALNEJ}

Współczesna gospodarka, oparta w głównej mierze na mechanizmie rynkowym, nie zawsze gwarantuje optymalne wykorzystanie zasobów. Już na początku XIX w. Jean-Babtiste Say stwierdził, że zarówno produkcja, jak i konsumpcja powodują przekształcanie materii, wskutek czego generowane są odpady i następuje zanieczyszczenie środowiska [Say 1960]. Również John Stuart Mill wyrażał opinię, że działalność gospodarcza może wywoływać środowiskowe efekty uboczne [Mill 1965]. Według Marka Blauga, efekty zewnętrzne występują zawsze wtedy, kiedy do funkcji produkcji danego przedsiębiorstwa wchodzą zmienne będące skutkiem działalności innych podmiotów [Blaug 1994]. Z kolei Joseph E. Stiglitz uznał, że efekt zewnętrzny powstaje wówczas, gdy jakaś osoba lub firma podejmuje działania, które wywierają wpływ na sytuację innych, a nie są one rekompensowane odpowiednią płatnością w jedną lub drugą stronę [Stiglitz 2004]. Pojęcie efektów zewnętrznych w znaczeniu współczesnej ekonomii wprowadził Arthur Pigou, postulując jednocześnie ich internalizację, to jest przypisanie negatywnych skutków działalności sprawcom i obarczenie ciężarem naprawy szkód [Pigou 1938]. Gdyby efekt zewnętrzny był dodatni, wówczas rolę podatku spełniałaby subwencja. W literaturze podatek Pigou traktowany jest jako ogólna przesłanka racjonalizacji ekonomicznej polityki ochrony środowiska [Fiedor 1990], realna polityka jest bowiem mieszaniną trzech komponentów: mechanizmu rynkowego, bodźców ekonomicznych i regulacji prawnych [Woś 1995]. Te teoretyczne konstatacje zostały wykorzystane do opracowania ekonomicznych mechanizmów wspierających ograniczanie emisji gazów cieplarnianych, w tym także poprzez rozwój wykorzystania odnawialnych źródeł energii.

Narzędzia wsparcia energetyki odnawialnej to instrumenty regulacyjne, finansowe oraz programy finansowania [Graczyk 2011]. Mechanizmy regulacyjne i finansowe odnoszą się głównie do wytwarzania energii i jej nośników. Ich kluczowym elementem są programy finansowania inwestycji z zakresu OZE. W Unii Europejskiej najważniejszymi źródłami finansowania od 2000 r. są Europejski Fundusz Rozwoju Regionalnego (EFRR) i Fundusz Spójności (FS). W latach 2000-2006 wsparcie projektów tego sektora z obu Funduszy wyniosło 0,6 mld euro. W kolejnym okresie programowania (2007-2013) było to już 4,7 mld euro [Wsparcie... 2014]. Ponadto niektóre działania mogły być finansowane w ramach wspólnej polityki rolnej (WPR).

W celu realizacji unijnej polityki energetycznej, poza działaniami politycznymi, prawnymi, administracyjnymi i finansowymi, prowadzone były i są także programy badawczo-rozwojowe wspierające rozwój OZE, między innymi: Altener, Coopener, Inteligentna Energia - Europa, Joule-Thermie, Save, Steer, Synergy oraz projekty kolejnych edycji Europejskiego Programu Ramowych Badań i Rozwoju Technicznego. Uzupełnieniem tych działań było rozszerzenie ofert o preferencyjne pożyczki, kredyty gwarantowane, a także pożyczki dla małych firm na inwestycje w energetykę odnawialną, przez takie instytucje finansowe, jak Europejski Bank Inwestycyjny (EBI) oraz Europejski Bank Odbudowy i Rozwoju (EBOiR). Z punktu widzenia potencjału finansowania inwestycji energetycznych 
najważniejszym źródłem są środki EBI, którego aktywność kredytowa jest zbieżna ze strategicznymi kierunkami rozwoju UE. Fundusze EBI oferowane są w postaci pożyczek oraz linii kredytowych [De Jager i in. 2011, Kawa 2015].

W Polsce przed integracją z UE najwięcej środków na inwestycje z zakresu energetyki odnawialnej było przyznawanych przez Narodowy Fundusz Ochrony Środowiska i Gospodarki Wodnej, wojewódzkie, powiatowe oraz gminne fundusze ochrony środowiska i gospodarki wodnej, a także Fundację Ekofundusz (zarządzającą konwersją polskiego długu zagranicznego). Ponadto inwestorzy mogli ubiegać się o dofinansowanie w Fundacji Programów Pomocy dla Rolnictwa (FAPA), obsługującej linie kredytowe Banku Światowego (np.: PAOW), Agencji Własności Rolnej Skarbu Państwa (od 1.09.2017 r. Krajowy Ośrodek Wsparcia Rolnictwa), Agencji Restrukturyzacji i Modernizacji Rolnictwa, Funduszu na Rzecz Globalnego Środowiska (GEF) zarządzanego przez Organizację Narodów Zjednoczonych ds. Rozwoju (UNIDO) lub środków finansowych wynikających z umów bilateralnych zawartych między rządem Polski i Danii, Szwecji, Holandii, Japonii, Finlandii, Szwajcarii oraz USA [Graczyk 2011, Letkowski 2011].

Wraz z akcesją Polski do UE nastąpiło znaczące zwiększenie dostępności środków finansowych na promocję stosowania energii z OZE. Środki te były alokowane w ramach Programu Operacyjnego Infrastruktura i Środowisko (POIiŚ), regionalnych programów operacyjnych (RPO) oraz Programu Rozwoju Obszarów Wiejskich (PROW). POIiŚ w zakresie OZE skierowany był na realizację krajowej polityki energetycznej, tradycyjnie skoncentrowanej na rozwoju dużych, scentralizowanych źródeł wytwarzania energii i obejmował następujące działania:

- 4.5. Wsparcie dla przedsiębiorstw w zakresie ochrony powietrza,

- 9.4. Wytwarzanie energii ze źródeł odnawialnych,

- 9.5. Wytwarzanie biopaliw ze źródeł odnawialnych,

- 9.6. Sieci ułatwiające odbiór energii ze źródeł odnawialnych,

- 10.3. Rozwój przemysłu dla odnawialnych źródeł energii.

W ramach tych działań łącznie udzielono wsparcia na realizację 73 projektów o wartości 1698 mln zł. Były to głównie elektrownie wiatrowe (48), biogazownie (14), elektrownie lub elektrociepłownie na biomasę (5), instalacje do produkcji biopaliw (3) oraz sieci przesyłowe ułatwiające odbiór energii elektrycznej wytworzonej z OZE (3). Środki te były przeznaczone na przedsięwzięcia o wartości powyżej $20 \mathrm{mln}$ zł, stąd też średnie dofinansowanie wynosiło $23,3 \mathrm{mln}$ zł. Wartość inwestycji zrealizowanych przy zaangażowaniu tych środków wyniosła 6,3 mld zł (w województwie lubelskim tylko 20,1 mln zł).

W związku ze specyfiką OZE (rozproszenie) dużo większe znaczenie dla rozwoju tego sektora miały środki Europejskiego Funduszu Rozwoju Regionalnego, z których w Polsce współfinansowano realizację RPO. Zarządzanie RPO (a więc zarówno przygotowanie, jak i wdrażanie) zostało powierzone zarządom poszczególnych województw. Dzięki temu strategie działania względem rozwoju OZE zostały dostosowane do uwarunkowań lokalnych (priorytetów rozwoju społeczno-gospodarczego, środowiska naturalnego, zasobów). W każdym województwie obowiązkowym elementem programu regionalnego było działanie związane z energetyką (w tym odnawialną), ochroną środowiska i efektywnością energetyczną. W ramach 16 RPO dofinansowano 657 projektów na kwotę 1,49 mld zł. Najwięcej środków na realizację inwestycji wykorzystujących OZE wydano z Regionalnego Programu Operacyjnego Województwa Lubelskiego.

Obszary wiejskie, z uwagi na ilościowy i jakościowy potencjał, są predestynowane do wytwarzania surowców energetycznych lub energii, stąd również w PROW przewidziano 
fundusze na rzecz rozwoju energetyki odnawialnej. Wsparcie dotyczące OZE w PROW 2007-2013 miało charakter wielokierunkowy i było udzielane w ramach 5 działań:

- 121. Modernizacja gospodarstw rolnych,

- 123. Zwiększanie wartości dodanej podstawowej produkcji rolnej i leśnej,

- 311. Różnicowanie w kierunku działalności nierolniczej,

- 312. Tworzenie i rozwój mikroprzedsiębiorstw,

- 321. Podstawowe usługi dla gospodarki i ludności wiejskiej.

W przeprowadzonych badaniach uwzględniono działanie 321 . w zakresie operacji dotyczących budowy mikroinstalacji prosumenckich wykorzystujących OZE do wytwarzania energii elektrycznej lub cieplnej przeznaczonej na potrzeby własne. Krajowa pula środków PROW na mikroinstalacje prosumenckie wykorzystujące OZE wyniosła 22,7 mln euro. Dofinansowanie operacji ze środków PROW dla jednej gminy wynosiło maksymalnie do 200 tys. euro w formule de minimis przy 90-procentowym poziomie dofinansowania.

\section{WYNIKI BADAŃ}

Spośród badanych programów i działań głównym źródłem finansowania projektów inwestycyjnych z zakresu OZE był Regionalny Program Operacyjny Województwa Lubelskiego (RPOWL), oś priorytetowa VI. Środowisko i czysta energia, działanie 6.2. Energia przyjazna środowisku. W jego ramach realizowano zamierzenia dotyczące wykorzystania energii z odnawialnych źródeł zgodne z Wojewódzkim Programem Rozwoju Alternatywnych Źródeł Energii dla Województwa Lubelskiego (WPRAZEWL), takie jak:

- inwestycje w rozwój i wykorzystywanie OZE wiatru, wody (z uwzględnieniem potrzeb ochrony przyrody i ekologicznych aspektów utrzymania rzek), biomasy, energii słonecznej i geotermalnej oraz pozostałych,

- inwestycje mające na celu redukcję emisji biogazu powstałego w oczyszczalniach ścieków i na wysypiskach poprzez jego energetyczne wykorzystanie,

- modernizacja kotłowni opalanych paliwem stałym na zasilane paliwem ekologicznym, ze szczególnym uwzględnieniem zadań realizowanych w placówkach oświatowo-wychowawczych, placówkach kulturalnych, szpitalach [Wojewódzki... 2006].

Beneficjentami programu były jednostki samorządu terytorialnego (JST) i ich związki, porozumienia, stowarzyszenia, samorządowe podmioty organizacyjne sektora finansów publicznych z osobowością prawną, spółki prawa handlowego, w których większość udziałów lub akcji posiadają JST lub ich związki, oraz podmioty działające w oparciu o ustawę z dnia 19 grudnia 2008 r. o partnerstwie publiczno-prywatnym [Dz.U. 2009.19.100]. Wartość dofinansowania dla projektów nieobjętych pomocą publiczną wynosiła maksymalnie do $85 \%$ kosztów kwalifikowanych. W ramach tego działania zrealizowano łącznie 72 projekty (79,1\% spośród objętych badaniem) o wartości $355 \mathrm{mln}$ zł (90,8\%) i dofinansowaniu w kwocie 265,5 mln zł (93,2\%) (tab. 1.).

Ponad 93\% tej kwoty rozdysponowano na inwestycje w energetykę ,słoneczną”, głównie kolektory słoneczne. Tak znaczące zainteresowanie wykorzystaniem energii słonecznej przez gospodarstwa domowe do przygotowania ciepłej wody użytkowej wynikało z możliwości uzyskania oszczędności z tytułu zmniejszonych wydatków ponoszonych na zakup nośników energii. Z badań przeprowadzonych w gminach Gorzków i Rudnik (woj. lubelskie) wynika, że zastosowanie kolektorów słonecznych może być efektywne ekonomicznie, nawet przy realizacji takich inwestycji ze środków własnych [Gradziuk, Gradziuk 2016]. 


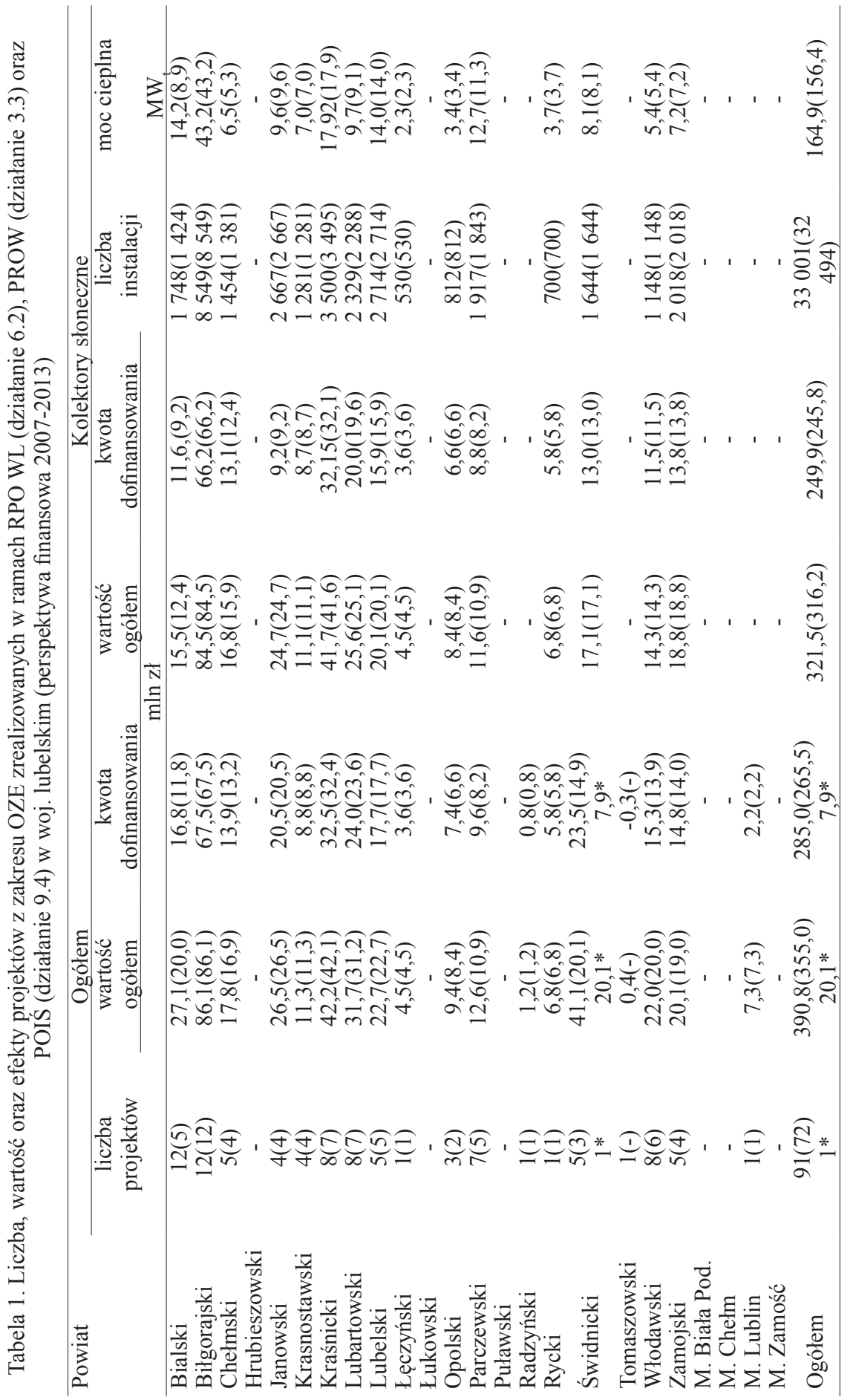


PRÓBA OCENY EFEKTÓW ABSORPCJI ŚRODKÓW Z FUNDUSZY EUROPEJSKICH NA ROZWÓJ...

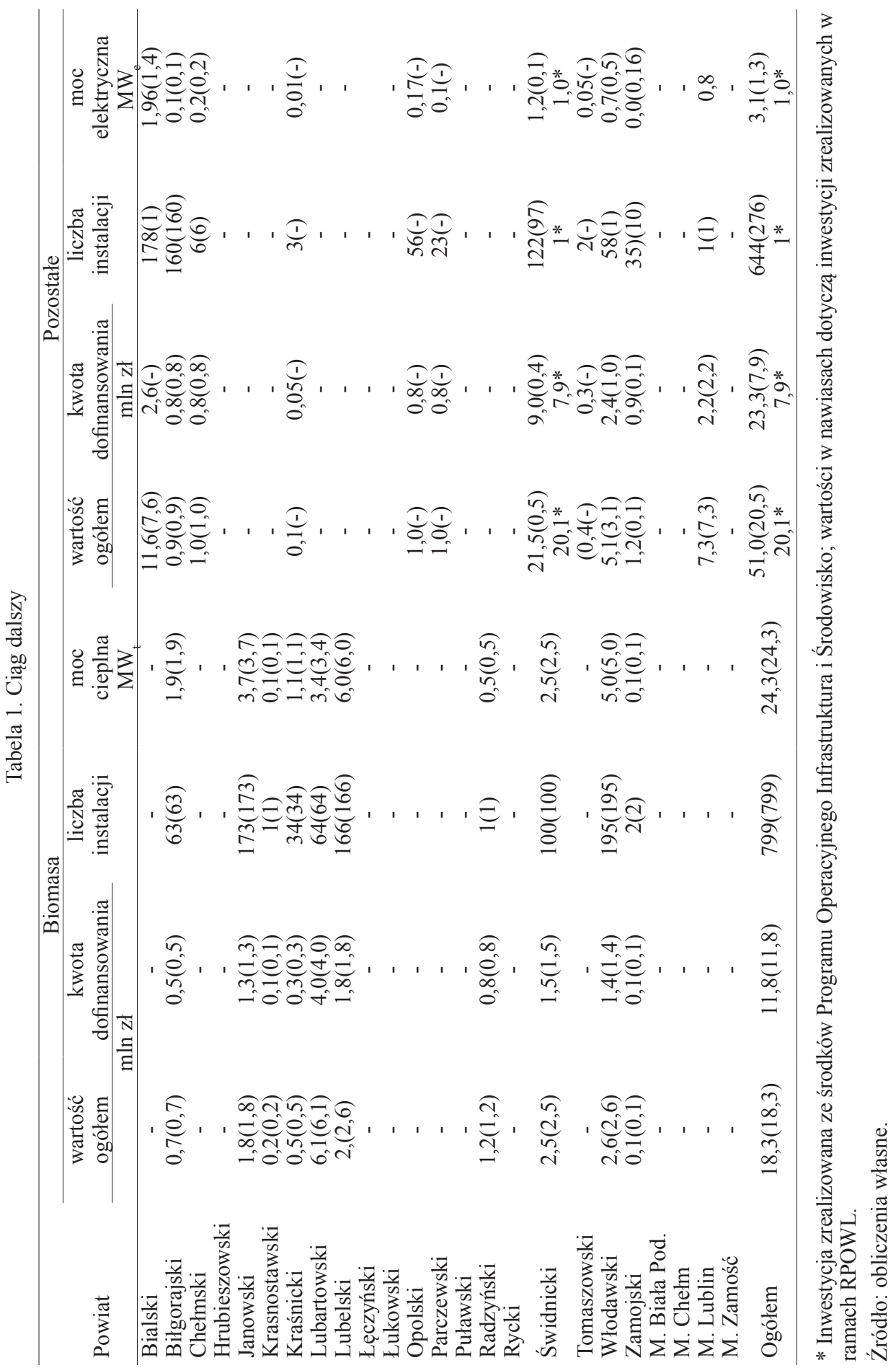


Wśród zrealizowanych projektów stosunkowo niewielki udział miały urządzenia, w których wykorzystywano biomasę, mimo iż z wielu badań wynika, że jej wykorzystanie pozwoliłoby, w zależności od powiatu, pokryć od $20 \%$ do $69 \%$ potrzeb cieplnych, najwięcej w powiatach parczewskim, hrubieszowskim, janowskim, biłgorajskim, kraśnickim i włodawskim [Szul 2014]. Również w Programie Rozwoju Odnawialnych Źródeł Energii dla Województwa Lubelskiego zapisano, że rozwój energetyki odnawialnej winien być realizowany na bazie biomasy pochodzenia rolniczego i z przemysłu rolno-spożywczego. Jednak na ich instalację wydatkowano tylko 4,4\% środków z działania 6.2.

Zainteresowanie beneficjentów wykorzystaniem energii słonecznej zostało potwierdzone efektami realizacji działania 321. Podstawowe usługi dla gospodarki i ludności wiejskiej, objętego Programem Rozwoju Obszarów Wiejskich w zakresie operacji dotyczących budowy mikroinstalacji prosumenckich. Wszystkie zrealizowane projekty (19) dotyczyły energetyki „słonecznej”. Jednak w odróżnieniu od działania 6.2. beneficjenci wykazywali dużo większe zainteresowanie urządzeniami z zakresu energetyki fotowoltaicznej (12) niż termicznej (7). Podstaw takich decyzji należy upatrywać w coraz niższych kosztach i wyższej efektywności energetycznej instalacji fotowoltaicznych (rys. 1.).

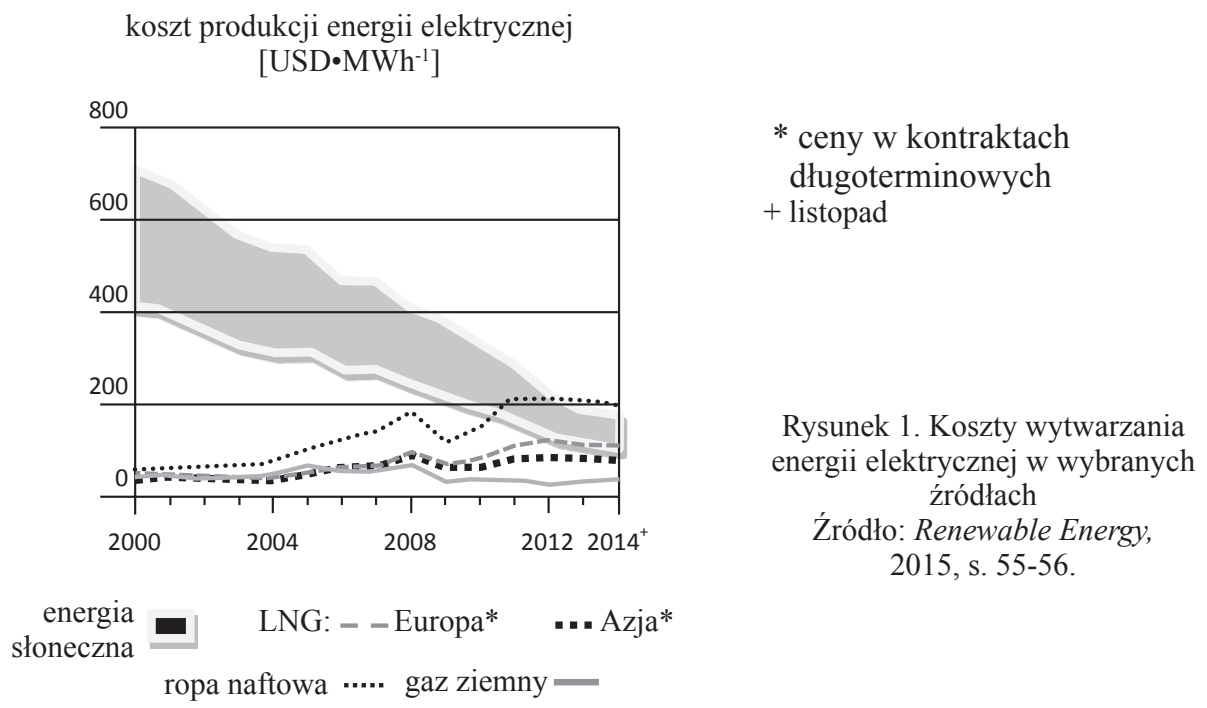

Duży udział projektów polegających na instalacji kolektorów słonecznych i paneli fotowoltaicznych sprawił, że województwo lubelskie stało się liderem pod względem wykorzystania energii słonecznej, co jest zgodne z założeniami Programie Rozwoju Odnawialnych Źródeł Energii dla Województwa Lubelskiego. Zaczyna się więc spełniać wizja Ryszarda Manteuffla, iż geniusz ludzki wynajdzie sposób korzystania bez ograniczeń $z$ energii słonecznej [Manteuffel 1987].

Chociaż wnioskodawcami w obu badanych działaniach były jednostki samorządu terytorialnego, to grupę docelową stanowiły przede wszystkim gospodarstwa domowe, głównie na wsi. Zamontowano w nich ponad 34 tys. instalacji, przeważnie kolektorów słonecznych $(95,8 \%)$, kotłów na biomasę $(2,3 \%)$ i paneli fotowoltaicznych $(1,9 \%)$. Klu- 
czowym czynnikiem determinującym znaczący udział projektów z zakresu energetyki „słonecznej” były bardzo niskie koszty eksploatacyjne oraz bezobsługowy charakter takich instalacji. Łączna moc urządzeń zainstalowanych w ramach zrealizowanych inwestycji wyniosła 189,2 MWt i 4,1 MWe, w efekcie czego nastąpiło zmniejszenie zużycia paliw konwencjonalnych na obszarach wiejskich o około 4\% w ciągu roku, co równoważne jest wartości energetycznej 19 tys. t węgla kamiennego. Podjęte w ramach analizowanych programów działania przyczyniły się również do redukcji emisji $\mathrm{CO}_{2}$ o około 1,7 tys. $\mathrm{t}$ (podstawowego gazu cieplarnianego) oraz pyłów i innych zanieczyszczeń.

W tabeli 1. przedstawiono strukturę alokacji środków w układzie powiatowym. Do najbardziej aktywnych pod względem liczby i wartości zrealizowanych projektów z zakresu OZE należały samorządy powiatu biłgorajskiego. Wydatkowane na ten cel środki stanowiły około $25 \%$ ogólnej kwoty będącej do rozdysponowania w ramach badanych działań. Zostały przeznaczone między innymi na zakup i montaż instalacji solarnych do podgrzewania ciepłej wody użytkowej w ponad 8,5 tys. gospodarstw domowych, to jest około $40 \%$ ogółu zlokalizowanych na obszarach wiejskich powiatu biłgorajskiego. W wyniku realizacji tych inwestycji o 25\% zmniejszono zużycie paliw konwencjonalnych przeznaczanych na ten cel. Dużą skutecznością w zakresie pozyskiwania środków na rozwój wykorzystania OZE wykazały się też samorządy z powiatu kraśnickiego (32,5 $\mathrm{mln}$ zł), lubartowskiego (24,0 mln zł), janowskiego (20, $5 \mathrm{mln}$ zł), lubelskiego (17,7 mln zł), bialskiego (16,8 mln zł), świdnickiego (15,6 mln zł), włodawskiego (15,3 mln zł), zamojskiego (14,8 mln zł) i chełmskiego (13,9 mln zł). W siedmiu powiatach, w tym trzech miastach na prawach powiatu, nie zrealizowano żadnej inwestycji w ramach analizowanego działania. Z przeprowadzonego rozeznania wśród władz samorządowych tych JST wynika, że na ich terenie działania inwestycje z zakresu OZE nie należały do priorytetowych.

W woj. lubelskim niewielkie zainteresowanie odnotowano w zakresie aplikowania o fundusze na rozwój wykorzystania OZE w ramach POIiŚ. Złożono tylko 12 wniosków, w tym 9 na biogazownie i 3 kolektory słoneczne. Spośród aplikacji złożonych do dofinansowania komisja konkursowa zakwalifikowała tylko jeden projekt (biogazownię). Wartość dofinansowania wyniosła 7,9 mln zł. Zasadniczą przyczyną okazała się zbyt wysoka minimalna wartość projektu (20 mln zł, a dla biogazowni $10 \mathrm{mln}$ zł). Ponadto projekty z tego zakresu mogły być realizowane, niekiedy na znacznie korzystniejszych warunkach, m.in. w ramach RPO WL, PROW czy też środków NFOŚiGW. Przyczyny odrzucania wniosków na etapie preselekcji były zróżnicowane, głównie odnosiły się do kompletności wniosku, w tym braku załączników lub negatywnej oceny wykonalności projektu.

\section{PODSUMOWANIE}

W Polsce występuje wielopoziomowy i zróżnicowany system finansowania projektów inwestycyjnych wykorzystujących OZE. Od 2007 roku znaczna część środków przeznaczanych na ten cel rozdysponowywana była na szczeblu wojewódzkim w ramach regionalnych programów operacyjnych lub - jak w przypadku PROW działanie 321. Podstawowe usługi dla gospodarki i ludności wiejskiej - została delegowana przez Ministra Rolnictwa i Rozwoju Wsi, pełniącego rolę instytucji zarządzającej, do poszczególnych samorządów wojewódzkich. Środki z obu funduszy w odróżnieniu od działań z Programu Operacyjnego Infrastruktura i Środowisko (np. 9.4.) stymulowały głównie rozwój energetyki prosumenckiej. Dominującą grupę beneficjentów stanowiły JST, w większości jednak 
skupiające grupowe projekty obejmujące indywidualnych inwestorów. Z przeprowadzonych badań wynika, że beneficjenci w ramach RPOWL i PROW instalowali głównie kolektory słoneczne, dla których średni poziom dofinansowania był najwyższy i wyniósł 77,7\% kosztów kwalifikowanych. W przypadku kotłów na biomasę i instalacji fotowoltaicznych wskaźniki te były niższe i wynosiły odpowiednio $64,5 \%$ oraz $49,8 \%$, a dla biogazowni zrealizowanej przy wsparciu środków finansowych POIiŚ tylko 39,3\%. Inwestycje te wniosły znaczący wkład w realizację Program Rozwoju Odnawialnych Źródeł Energii dla Województwa Lubelskiego oraz Krajowego Planu Działania w Zakresie Odnawialnych Źródeł Energii [2010].

Zaprezentowane wyniki opracowano na podstawie sprawozdań ze zrealizowanych projektów, które obejmowały tylko informacje o nakładach inwestycyjnych i podstawowe charakterystyki instalowanych urządzeń. Wskazana byłaby więc kontynuacja rozpoczętych badań w zakresie ekonomicznej efektywności produkcji energii i redukcji emisji $\mathrm{CO}_{2}$ poprzez zastosowanie OZE, z uwzględnieniem poszczególnych technologii. Zebrane doświadczenia mogłyby służyć racjonalizacji alokacji funduszy na rzecz rozwoju OZE w kolejnym okresie programowania.

\section{LITERATURA}

Blaug Mark, 1994: Teoria ekonomii. Ujęcie retrospektywne. PWN, Warszawa, s. 60-102.

De Jager David, Corinna Klessmann, Eva Stricker, Thomas Winkel, Erika De Visser, Michele Koper, 2011: Financing Renewable Energy in the European Energy Market. Ecofys, s. 57.

Fiedor Bogusław, 2010: Kryzys gospodarczy a kryzys ekonomii jako nauki. „Ekonomista”, nr 4, s. 453-466.

Fiedor Bogusław, 1990: Przyczynek do ekonomicznej teorii zanieczyszczenia i ochrony środowiska. PAN, Wrocław, s. 8-9.

Graczyk Andrzej, 2011: Problemy dofinansowania odnawialnych źródet energii ze środków publicznych. „Ekonomia i Środowisko”, nr 2(40), s. 72-89.

Gradziuk Piotr, Zygmunt Wojtaszek, 2001: Alternatywne wykorzystanie gruntów rolniczych na cele niezwiązane z produkcją żywności, [w] Procesy dostosowawcze produkcji roślinnej w Polsce w kontekście integracji z Unia Europejska, red. Klepacki B. Wydawnictwo SGGW, Warszawa, s. $213-228$

Gradziuk Piotr, Barbara Gradziuk, 2016: Economical end ecological efficiency of solar systems (A Case Study at the Communes Gorzkow and Rudnik). „Barometr Regionalny. Analizy i Prognozy", nr 14(3), s. 189-195.

International Energy Outlook 2002, 2003: Energy Information Agency, U.S. Department of Energy, Washington.

Kawa Joanna, 2015: Programy wsparcia instalacji OZE w Polsce. „InstalReporter”, nr 7, s. 24.

Key Word Energy Statistic 2006-2014, 2014: International Energy Agency, „BP Statistical Review of Word Energy", June 2014, s. 48.

Komunikat Komisji dla Rady, Parlamentu Europejskiego, Europejskiego Komitetu Ekonomiczno-Społecznego i Komitetu Regionów. Plan działania prowadzacy do przejścia na konkurencyjna gospodarkę niskoemisyjna do 2050 roku, Bruksela, dnia 08.03.2011, KOM (2011) 112, wersja ostateczna, s. 8.

Krajowy Plan Działania w zakresie energii ze źródeł odnawialnych, 2010: Ministerstwo Gospodarki, Warszawa.

Letkowski Dariusz, 2011: Finansowanie odnawialnych źródet energii w Polsce. „Acta Universitatis Lodziensis, Folia Oeconomica", nr 260, s. 101-116.

Manteuffel-Szoege Ryszard, 1987: Filozofia rolnictwa, PWN, s. 14.

Mill John Stuart, 1965: Zasady ekonomii politycznej, t. II, PWN, Warszawa, s. 488-489.

Pigou Arthur, 1938: The Economics of Welfare. Macmillan. London, s. 134-242. 
Program Rozwoju Odnawialnych Źródeł Energii dla Województwa Lubelskiego, 2014: Urząd Marszałkowski Województwa Lubelskiego.

Renewable Energy. Not a toy. „The Economist”, April 11th-17th 2015, s. 55-56.

Say Jean-Babtiste, 1960: Traktat o ekonomii politycznej. PWN, Warszawa.

Stiglitz Joseph Eugene, 2004: Ekonomia sektora publicznego. PWN, Warszawa, s. 254.

Szul Tomasz, 2014: The spatial diversity of the share the local sources of biomass in meeting of heat needs on the rural areas of Lublin Province. „Barometr Regionalny”, nr 12(2), s. 77-83.

Toffler Alvin, 1997: Trzecia fala. PIW, Warszawa, s. 38.

Wojewódzki Program Rozwoju Alternatywnych Źródet Energii dla Województwa Lubelskigo, 2006: Urząd Marszałkowski Województwa Lubelskiego.

Woś Augustyn, Józef Zegar, 2002: Rolnictwo społecznie zrównoważone. IERiGŻ, Warszawa, s. 13-14. Woś Augustyn, 1995: Ekonomika odnawialnych zasobów naturalnych. PWN, Warszawa, s. 13-146. Wsparcie z funduszy polityki spójności na rzecz wytwarzania energii ze źródel odnawialnych - czy osiagnięto dobre rezultaty? 2014: Europejski Trybunał Obrachunkowy, Luksemburg.

\section{Piotr Gradziuk, Barbara Gradziuk}

\section{THE ATTEMPT OF EVALUATION OF ABSORPTION OF THE EUROPEAN FUNDS FOR THE DEVELOPMENT OF USE OF RENEWABLE ENERGY SOURCES IN LUBELSKIE PROVINCE}

\section{Summary}

The paper presents results of study aimed at assessing an absorption of European Union funds intended for investments in renewable energy in the Lubelskie province. Source of the data was the Department of Regional Operational Programme in the Marshal's Office for Lubelskie province in Lublin and the Department of European Funds in Ministry of Energy. With the funds from the Regional Operational Programme of the Lubelskie province and the Rural Development Programme (3.2.1) over 34 thousand renewable energy installations with capacity of 189,2 MWt and 4,1 MWe, were build. Most of them were solar collectors (95.8\%), biomass boilers $(2.3 \%)$ and photovoltaic panels (1.9\%). Such significant share of solar energy projects proves the hypothesis of the Renewable Energy Development Program for the Lubelskie province that it is possible for the Lubelskie region to become a national leader in the use of solar energy for the production of heat and electricity. As a result of implemented projects the consumption of conventional fuels in rural areas dropped by around $4 \%$ per year, what is equal to the energy value of 19 thousand tons of bituminous coal. Furthermore, actions taken with the help of above mentioned programs resulted in a reduction of $\mathrm{CO}_{2}$ emissions by around 1,7 thousand tons of primary greenhouse gas, dust and other pollutants.

Adres do korespondencji: Dr hab. Piotr Gradziuk

Państwowa Szkoła Wyższa im. Papieża Jana Pawła II w Białej Podlaskiej ul. Sidorska 95/97, 21-500 Biała Podlaska e-mail: p.gradziuk@dydaktyka.pswbp.pl

Dr Barbara Gradziuk Uniwersytet Przyrodniczy w Lublinie Wydział Agrobioinżynierii, Katedra Zarządzania i Marketingu ul. Akademicka 13, 20-950 Lublin, tel. (81) 4610061 w. 196 e-mail:barbara.gradziuk@up.lublin.pl 